Assessing Treatment Barriers in Eating Disorders: A Systematic Review 


\begin{abstract}
This systematic review evaluated methods used to assess treatment barriers among individuals with eating disorders or disordered eating. Eleven studies were identified and evaluated according to attributes considered important in the accurate assessment of treatment barriers. The majority of studies used qualitative methods, with five studies utilising either a checklist or scale-based instrument. Adequate psychometric investigation was lacking. This review highlights the paucity of research examining barriers to accessing and/or receiving treatment in disordered eating populations. There is a need for development of psychometrically sound instruments that assess the range and relative interference of specific barriers experienced in this population.
\end{abstract}

Keywords: treatment barriers, barriers to care, eating disorders, anorexia nervosa, bulimia nervosa 


\section{Assessing Treatment Barriers in Eating Disorders: A Systematic Review}

Although many individuals with eating disorders report a perceived need for treatment, relatively few end up receiving treatment (Cachelin, Rebeck, Veisel, \& Striegel-Moore, 2001; Mojtabai, Olfson, \& Mechanic, 2002). The number of individuals with an eating disorder who access treatment in a single year is considerably less (19-36\%) than those with other types of mental health problems (35-41\%; Cachelin \& Striegel-Moore, 2006; Hart, Granillo, Jorm, \& Paxton, 2011; Vanheusden et al., 2008). In addition, treatment for an eating disorder is sought an average of 10-15 years after the onset of their illness compared to an average 8.2 year delay in those with mood or anxiety disorders (Oakley Browne, Elisabeth Wells, \& Mcgee, 2006; A. Thompson, Hunt, \& Issakidis, 2004). When professional help is sought, psychologists are less frequently accessed compared to other professionals (Evans et al., 2011). Therefore, understanding the types of barriers unique to receiving psychological help in individuals with eating disorders is imperative. Essential to this task is the identification of suitable measures for assessing and understanding barriers to treatment. The purpose of the current paper was to systematically review the literature, in order to identify and critically appraise measures for identifying individual's barriers to psychological treatment for eating disorders.

Barriers to treatment can encompass many facets including individual characteristics (e.g. attitudes/beliefs and treatment history), socio-environmental factors (e.g. availability of services and affordability), and treatment system factors (treatment options, eligibility criteria and location of service), all of which may impact upon an individual accessing treatment (Allen \& Dixon, 1994; Rapp et al., 2006). Allen and Dixon (1994) defined barriers in the context of help-seeking as a "subjective phenomena which includes beliefs or perceptions arising from within the person; and/or external phenomena such as the health care system, structural characteristics of programs, socio-cultural-environmental factors, and/or anything that 
constructs, restraints, or serves as an obstacle to the person receiving care or treatment for a particular problem" (p. 168). Stefl and Prosperi (1985) defined barriers to service use as involving multiple attributes: availability, accessibility, acceptability and affordability. A descriptive review of the literature published during the conduct of the present review identified key themes in barriers to care for eating disorders, such as personality traits, ethnicity and culture, health beliefs, physician beliefs, financial barriers, geographical barriers, and stigma (C. Thompson \& Park, 2016). However, the identification of barriers within these studies has been largely dependent upon the method and focus of assessment. That is, the barriers identified are influenced by the measure and format of the assessment. Qualitative approaches may only identify those barriers most salient to the individual at the time, whilst checklist approaches may not allow scope for elaboration or interpretation of barriers. As yet, no consensus has been reached on the most appropriate ways to examine treatment barriers.

\section{The Current Study}

The aim of the current paper was to systematically review methods for the measurement of barriers to treatment for eating disorders. A range of attributes was considered important for a measure to comprehensively and accurately assess treatment barriers, such as assessment format, psychometric properties, and scoring method. As a secondary aim, the main barriers identified by the included studies were also explored. The review was designed so as to provide researchers and clinicians with a guide to existing measures and identified barriers, as well as to provide direction for future research in this area.

\section{Method}

\section{Search strategy}

A systematic review of the literature was conducted to identify articles investigating treatment barriers in relation to eating disorders. This systematic review adhered to the Preferred Reporting for Items for Systematic Reviews checklist (PRISMA; Moher, Liberati, Tetzlaff, 
Altman, \& Group, 2010), however, it was not registered nor was a protocol published prior to the completion of the review. Two electronic databases, PsycINFO and PubMed, were searched using database subject headings (specific to PsychINFO or PubMed) and text searches with key words such as eating disorder*, bulimia nervosa (BN), anorexia nervosa (AN), binge-eating disorder (BED), purg*, bing*, "help seeking”, treatment barriers, barrier*, and engag*. The specific search strategies for the two databases are outlined in Appendix A. In addition, a manual search for relevant articles was conducted using Google Scholar. The reference lists of included articles were also searched for further relevant articles.

Searches were not limited by year of publication or article type, but were limited to being published in the English language. Searches, eligibility assessment, and data extraction were performed independently in an unblended standardized manner by two reviewers. Discrepancies between reviewers were resolved by discussion and consensus.

\section{Selection criteria}

Figure 1 displays the results of the systematic review. The initial database search generated 2067 results, with one additional article identified through the manual search of reference lists. Articles were screened by title and abstract, and then by full text. For inclusion studies were required to 1) assess barriers to psychological treatment 2) assess a range (>1) of barriers and 3) include an eating disorder/disordered eating sample. Accordingly, studies that did not directly address barriers to help-seeking/treatment/care for an eating disorder/disordered eating were excluded (i.e., indirectly reported on some barriers in the context of patients' views of eating disorder services; Escobar-Koch et al., 2010). The decision was made to include studies that assessed treatment barriers among both eating disordered (no restrictions on diagnostic criteria employed) and disordered eating (e.g. subclinical eating disorder) populations, so as to allow for a comprehensive review of the literature. Furthermore, studies that targeted only one specific barrier (i.e., social anxiety; Goodwin \& Fitzgibbon, 2002) were 
excluded as a comprehensive assessment of barriers to treatment for eating disorders was required for inclusion. This screening resulted in 11 relevant articles being identified.

\section{Data Extraction}

To comprehensively assess the validity and utility of each assessment measure, data were extracted relating to sample and recruitment, assessment method, type of treatment and professional source, as well psychometric properties and scoring.

Sample and Recruitment. In order to understand barriers to treatment it is vital to consider an individual's history of treatment-seeking behaviours. Arguably, barriers to treatment could be assessed by categorising individuals with eating disorders into separate groups: those who have never received treatment, those who received a referral but did not follow through with treatment, those who attended treatment but not to completion, and those who have completed treatment. Assessment of all individuals at each stage of the treatment-seeking process is preferable to ensure a comprehensive assessment of treatment barriers.

The specific diagnoses being investigated are also important to consider. Ideally, the spectrum of eating behaviours should be captured in a sample in order to comprehensively identify all barriers to treatment experienced by this population. Furthermore, ensuring that individuals with a range of diagnoses are assessed allows for important comparisons to be made between diagnostic groups in terms of barriers to treatment. Capturing barriers experienced by individuals with sub-clinical disordered eating symptoms is likely to offer important information to assist early intervention. Assessment should target the continuum of eating disorder behaviours to gain a complete understanding of the type and severity of barriers experienced. Therefore, the utility of each scale was considered within the context of the sample and recruitment characteristics of the study.

Assessment Method. In the broader mental health literature a number of published assessments for barriers to care exist. These assessments are typically of interview, checklist, or 
scale formats. Although each of these formats is associated with unique strengths and limitations, scale based measures are generally considered to be the most advantageous in terms of allowing relative degree of interference of each barrier to be inferred, comprehensive assessment, and standardised administration and comparison across individuals and groups. As a review of this nature has not been conducted within the eating disorder area to date, it was deemed of particular importance to review each measure with regards to assessment method and the associated advantages and disadvantages of each.

\section{Type of Treatment and Professional Source}

When considering barriers to seeking treatment for an eating disorder, it is important to specify the nature of treatment or service and/or professional source. This is pertinent given the range of professionals that are typically involved in the management of the patient and the differences in treatment-seeking according to professional sources (Cachelin \& Striegel-Moore, 2006; Mond, Hay, Rodgers, \& Owen, 2008). An Australian study investigating health service utilisation in women with $\mathrm{BN}$ found that, of those who had received help, only $11 \%$ had received help from a psychologist specifically for their eating disorder (Hart et al., 2011). These results suggest that there may be specific barriers to receiving psychological help, which warrant investigation. Further, research has shown that seeking treatment for mental health problems varies according to source (informal and professional) as well as the type of perceived barriers (Sheffield, Fiorenza, \& Sofronoff, 2004). Despite this, barriers are commonly considered in the context of mental health service utilisation, which could include an array of professionals (GP, psychiatrist, psychologist, social worker or counsellor). This makes it difficult to disentangle the relative influence of each source in terms of perceived barriers. Similarly, the type of treatment is equally as important when assessing barriers. Mohr et al. (2006) highlighted that there is a key distinction between various forms of treatment (e.g. psychological and pharmacotherapy) given that the barriers are likely to be different for each treatment. Therefore, measures that specify the 
nature of the treatment and the professional source can provide the clearest results in terms of specific barriers encountered. As such, data were extracted relating to specification of professional or treatment source.

\section{Psychometric Properties and Scoring}

Assessment of the psychometric properties of an instrument is necessary to ensure the results are reliable, valid, and able to be generalised to the wider eating disorder population. This includes an explanation of the development of the scale, justification for the selection of the items, scoring method, and reporting the psychometric properties of the scale (Mokkink et al., 2010). The generation of a total and/or subscale score is also important as it permits comparison between individuals and diagnostic groups. Further, a total score also captures the magnitude of the barriers an individual may be experiencing. In addition, the use of a rating system that allows for the degree of influence that each barrier exerts permits a detailed assessment of all barriers that may be preventing or delaying treatment. As such, each measure was also reviewed with regards to psychometric properties and scoring.

\section{Study Quality}

As the present review was concerned with the measurement of treatment barriers rather than efficacy or intervention effects, traditional attributes of study quality or risk of bias (e.g. randomisation, allocation concealment) were deemed inappropriate. Rather, the quality of studies was reviewed descriptively throughout the results, with reference to the previously described attributes of treatment engagement and help seeking status, specific diagnosis, type of treatment and professional source, and psychometric properties and scoring.

\section{Data Analysis and Synthesis}

Data were analysed in a qualitative manner across the extracted attributes of interest. This analysis focused on the primary aim of the study, to critically evaluate methods for 
assessing barriers to treatment in the eating disorder field, and the secondary aim, to summarise the primary barriers identified in the included studies.

\section{Results}

Table 1 summarises the sample characteristics and assessment formats of the studies meeting the inclusion criteria. Data were extracted in accordance with the previously identified attributes regarding the measurement of barriers to treatment in eating disorder populations.

[approximate location of Table 1]

\section{Sample and recruitment}

In all studies, measures were tested on adults with the exception of Meyer (2001) who used an adolescent sample (15-19 years). Sample sizes were generally small (range $=5-63$ ) with the exception of three studies (Cachelin \& Striegel-Moore, 2006; Meyer, 2001; Pepper, 2009) that had larger sample sizes $(N=106-238)$. In three studies the investigation of barriers was limited to a subsample of the total participant pool (Cachelin et al., 2001; Cachelin \& Striegel-Moore, 2006; Meyer, 2001). For example, the measure was only delivered if the participant indicated they had never sought or had become unwilling to seek treatment (Cachelin \& Striegel-Moore, 2006). Eight studies restricted the sample to only female participants whilst Leavey et al. (2011) included one male participant, Becker et al. (2010) included three males, and Dearden and Mulgrew (2013) utilised a male only sample $(N=5)$. The ethnicity of the participants varied, with four studies (Becker et al., 2010; Cachelin et al., 2001; Cachelin \& Striegel-Moore, 2006; Reyes-Rodriguez, Ramirez, Davis, Patrice, \& Bulik, 2013) focusing on the inclusion of "ethnic minority groups". For example, Reyes-Rodriquez et al. (2013) restricted the sample to Latinos while Cachelin and Striegel-Moore (2006) only included Mexican American and European American women. Becker et al. (2010) and Cachelin et al. (2001) however, described their samples as "ethnically diverse" with a range of ethnicities sampled 
(such as Hispanic, Asian, African American and Caucasians). Accordingly, samples across studies were relatively small, predominantly female, and from a variety of ethnicities.

Eating disorder characteristics. In six studies participants were individuals with a current diagnosable eating disorder living in the community. In two studies a disordered eating sample was utilised, with participants reporting difficulties with eating behaviours but without diagnostic criteria assessed (Dearden \& Mulgrew, 2013; Pepper, 2009). The remaining three studies (Becker et al., 2010; Crawford, 1998; Reyes-Rodriguez et al., 2013) included individuals with either a current or a past history of an eating disorder. Four studies focused on individuals across a range of DSM-IV-TR eating disorder diagnoses (AN, BN, BED, and Eating Disorder Not Otherwise Specified (EDNOS); Cachelin et al., 2001; Cachelin \& Striegel-Moore, 2006; Meyer, 2001; Reyes-Rodriguez et al., 2013). Three studies had a primary focus on women with bulimic behaviours and therefore did not directly assess AN (Crawford, 1998; Evans et al., 2011; Hepworth \& Paxton, 2007). Evans et al. (2011), Meyer (2001) and Reyes-Rodriguez et al. (2013) were the only three studies to also include individuals with sub-clinical eating disorder symptoms. However, with the exception of Meyer (2001) which included 78 sub-clinical cases, the other two studies had only a small number of sub-clinical cases ( $n$ ranged from $1-12$ ). Dearden \& Mulgrew (2013) and Pepper (2009) utilised samples with disordered eating but did not investigate diagnoses. The remaining two studies failed to report the eating disorder characteristics of the sample (Becker et al., 2010; Leavey et al., 2011). Therefore, across studies the majority of presentations were clinical eating disorders with few samples including the spectrum of eating disorder behaviours.

Treatment history. Most studies examined individuals who had never sought help for their eating disorder or those who had been referred for treatment but did not engage in the service (Cachelin et al., 2001; Cachelin \& Striegel-Moore, 2006; Leavey et al., 2011; Meyer, 2001; Pepper, 2009). Four studies assessed barriers in those who had a past treatment history, 
were referred to a service and/or were currently receiving treatment (Becker et al., 2010; Crawford, 1998; Dearden \& Mulgrew, 2013; Reyes-Rodriguez et al., 2013). Two studies examined barriers in individuals at any stage in the help-seeking process, with or without a prior treatment history (Evans et al., 2011; Hepworth \& Paxton, 2007). Therefore, across studies, barriers were assessed retrospectively and prospectively depending on the past treatment history of the sample.

\section{Assessment Method}

The most common method used to assess barriers involved a qualitative approach in the context of a larger semi-structured interview (Becker et al., 2010; Evans et al., 2011; Hepworth \& Paxton, 2007; Leavey et al., 2011; Reyes-Rodriguez et al., 2013). Dearden \& Mulgrew (2013) utilised a questionnaire requiring open text responses from individuals. The remaining studies utilised questionnaires or checklists with varying numbers of items (range $=6$ - 26; Cachelin et al., 2001; Cachelin \& Striegel-Moore, 2006; Crawford, 1998; Meyer, 2001; Pepper, 2009). These methods are examined in detail below.

Interviews. Various open-ended questions were used to explore barriers. For example, Hepworth and Paxton (2007) asked "Were there any barriers that prevented you or made you reluctant to seek help?". Similarly, Evans et al. (2011) assessed barriers by asking "Did anything come up that was a barrier? Or that has prevented you from talking about what you wanted to?". Two studies retrospectively assessed barriers by examining interview transcripts. Becker et al. (2010) reviewed qualitative data collected in 1998 and 1999 as part of a cross-sectional study investigating patients' experience with eating disorder treatment. Open-ended questions asked participants to describe their experience in seeking and receiving treatment as well as their experience of difficulties encountered in seeking care. Leavey and colleagues (2011) employed a slightly different method and audited new patient referrals to an eating disorder unit in order to identify patients who did not attend their first appointment or dropped out after the initial 
assessment session. Barriers were examined in follow-up interviews where patients were asked about their reasons for not engaging in the service (Leavey et al., 2011). Reyes-Rodriguez et al. (2013) used open ended questions such as "which factors could make the process of seeking and receiving professional help more difficult?”. Dearden and Mulgrew (2013) asked their male respondents about experiences of barriers to treatment, but did not report detail of the questions used. In summary, these qualitative studies used similar methods to broadly capture barriers/difficulties encountered in the treatment-seeking process.

Checklists. Two studies utilised a checklist to assess barriers. Meyer (2001) asked participants to endorse items from a list of six reasons for not seeking counselling for eating/dieting concerns. The items were derived from previous research examining reasons for delaying or avoiding help-seeking for personal or emotional problems (Amato \& Bradshaw, 1985; Rickwood \& Braithwaite, 1994). Similarly, Cachelin et al. (2001) used an eight item checklist administered verbally where participants who had never sought treatment for an eating disorder were asked to endorse those barriers which influenced their decision not to seek treatment. The items were generated from literature pertaining to treatment barriers to mental health care use. Overall, these two studies shared similarities including using the literature to generate barrier items and restricting assessment to only those who had never sought treatment.

Rating scales. Three studies assessed barriers using a structured scale-based instrument. Cachelin and Striegel-Moore (2006) used an instrument that had 19 statements regarding possible barriers which were rated on a 5-point level of agreement scale. The items included in this scale were largely derived from previous research (Cachelin et al., 2001; Keefe \& Casas, 1980; Marin, Marin, Padilla, \& De La Rocha, 1983). Selection criteria and method used to identify these specific items was not reported. Pepper (2009) utilised a similar approach with an instrument containing 26 items, largely based on Cachelin \& Striegel-Moore's (2006) previous scale. Again, participants responded to each barrier on a 5-point level of agreement scale. 
Finally, Crawford (1998) used a 20 item instrument with participants rating the degree to which they were influenced by each barrier on 10-point rating scales. Items for Crawford's measure were adapted from research on influences on women's utilisation of alcohol treatment (Beckman \& Amaro, 1984) and help seeking for drinking problems (Tucker, 1995).

\section{Response Format}

As the majority of studies were qualitative in nature, these participants responded to an open-ended question about any barriers to help-seeking or receiving professional treatment (Becker et al., 2010; Dearden \& Mulgrew, 2013; Evans et al., 2011; Hepworth \& Paxton, 2007; Leavey et al., 2011; Reyes-Rodriguez et al., 2013). Two studies (Cachelin et al., 2001; Meyer, 2001) required either a dichotomous (yes/no) response to each barrier or for participants to endorse only those barriers that applied. Cachelin and Striegel-Moore (2006), and Pepper (2009) administered a self-report study-specific instrument and asked participants to rate the level of agreement/disagreement on 5-point rating scales. This allowed mean scores for each item to be calculated as well as total barriers scores. Whilst the scale-based instruments included a greater number of barriers, and had the potential for greater interpretation, little additional information beyond that yielded from the checklists could be provided with these agreement scales. Therefore, the format used to assess barriers in all studies only generated information on the types of barriers experienced with the relative influence of specified barriers remaining undetermined. Crawford (1998) also utilised a scale based response format, but with respondents indicating the degree to which the barrier influenced their decision not to use formal treating services for their eating disorder. A total barriers score was not calculated by Crawford (1998), although items were combined and averaged to produce subscale or "factors" (e.g. preference to solve the problem by one's self or beliefs about the seriousness of the problem) based on item correlations and conceptual understanding. Factor scores were then statistically compared to determine the relative influence of each factor on treatment seeking. 
Psychometric Properties. A general lack of rigour was observed with regards to psychometric investigation of the barriers measures. Of the five studies that utilised either checklist or rating scale assessment methods, four reported no psychometric investigation of the measurement instrument used. As discussed, Crawford (1998) created factors that described items that were statistically and conceptually related. However, these factors were created on the basis of item correlations, with no other statistical (e.g. factor analysis, internal consistency of factors) investigation undertaken to support the psychometric properties of the measure.

Type of treatment and professional source. The majority of studies failed to specify the type of treatment and/or the professional source of help in which the barriers were considered. For example Becker et al. (2010)reported that respondents were asked to discuss decisions and difficulties encountered in both seeking and receiving "treatment for eating and weight concerns".. Only two studies specified the type of treatment or professional source for which the barriers to care related; one specified the particular service, an outpatient eating disorder clinic (Leavey et al., 2011), and the other specified professional counselling as the type of treatment (Meyer, 2001).

\section{Barriers measured or extracted}

For the qualitative studies, responses were generally coded into broad barrier themes. Becker et al. (2010) coded themes in an exploratory manner, with transcripts coded relating to specific barrier categories defined as "stereotyping, social norms that impact on help-seeking, socio-demographic factors impacting on communication or empathy in a clinical encounter, and financial constraints and treatment resource availability" (pg 635). This resulted in the identification of two overarching barriers; culturally-based factors and societal factors.

Reyes-Rodriguez et al. (2013) utilised a grounded theory approach to understanding treatment barriers. The most frequent barriers identified were classified into six categories: lack of information around eating disorder, language, economic barriers, emotional/personal barriers, 
cultural stigmas, and transportation. Evans et al. (2011) conducted a thematic analysis to derive barriers to help-seeking. The categories yielded were: cost, lack of time, service constraints and personal/emotional issues. In Dearden and Mulgrew's (2013) thematic analysis, the barriers of lack of awareness of the nature of their problem and treatment options, problems with recognition of men's eating issues within the health care system, motivation, perceived usefulness of treatment, cost, and travel distance.

Leavey et al. (2011) extracted data using Interpretative Phenomenological Analysis (IPA) which aims to capture the underlying meaning of the individual's experience. Two themes were derived from the analysis: psychosocial factors and service related and/or practical problems. Hepworth and Paxton (2007) used a concept mapping program (Leximancer) to classify barrier themes and identified barriers such as fear of stigma, low mental health literacy, shame, fear of change, and cost.

Those studies that utilised a quantitative design (Cachelin et al., 2001; Cachelin \& Striegel-Moore, 2006; Crawford, 1998; Meyer, 2001; Pepper, 2009) were examined for specific barriers or domains addressed within the measure. Most studies did not differentiate between different types of barriers. Instead, barrier items were grouped together and examined collectively without any categorisation into subscales. Pepper (2009) grouped barriers broadly into individual level and system level barriers, whilst Crawford (1998) used correlations and conceptual understanding to create seven treatment barrier factors.

Key treatment barriers identified. Table 2 reports the key barriers identified in order of priority for each study. For the five qualitative studies, the types of barriers generated varied across studies making direct comparisons difficult. However, similar barriers identified across the 11 studies included: shame/stigma, poor mental health literacy, perceived need for treatment, unhelpful past treatment experience, fear of change, low motivation, service restrictions (e.g. being ineligible to access a service due to strict entry criteria), and cost. Differences emerged 
between the studies, with only those studies that included a specific ethnic sample identifying cultural and language barriers. Further, the barriers identified by Meyer (2001) differed somewhat in comparison to the other studies (did not want parents to know) given that an adolescent sample was used. Similarly, Dearden and Mulgrew's (2013) male sample also identified unique barriers such as lack of recognition of men's eating problems in the healthcare system.

[approximate location of Table 2]

\section{Discussion}

The aim of this study was to review the measurement of barriers to treatment in disordered eating populations. A comprehensive search identified 11 studies that have directly investigated barriers specific to receiving treatment for an eating disorder. These 11 studies were reviewed in terms of their method of assessing barriers according to the attributes identified as important in measurement of treatment barriers. Barriers such as shame and stigma, service related factors and cost were among the most commonly reported. However, comparison between the qualitative studies was difficult, given the variability in barriers identified. Similarly, comparison between the quantitative studies was not possible and the interpretation was limited to the number and types of barriers included in the measure. Overall, these results highlight a need for further research into treatment barriers in the eating disorders to address a number of limitations.

\section{Limitations identified in the research}

Many studies lacked adequate sample sizes to draw conclusions about treatment barriers in this population. Further, the representation across diagnostic groups was uneven, with often an overrepresentation of cases with BED and $\mathrm{BN}$ and underrepresentation of cases with $\mathrm{AN}$, and to a lesser extent EDNOS. Further, most studies failed to include the whole spectrum of eating 
disorder behaviours, excluding those with sub-clinical eating disorder symptoms. Exclusion of those with sub-clinical symptoms is problematic as it prevents a comprehensive understanding of barriers to be gathered in this population.

The majority of research to date has been exploratory with little attempt to build upon these findings and confirm the barriers already identified in a more structured manner. The few studies that have quantitatively assessed barriers have developed instruments without a clear justification for the items and importantly the instruments have lacked psychometric rigor. Indeed, none of the included studies reported on any examinations of reliability or validity of the measures used. Only three studies (Cachelin \& Striegel-Moore, 2006; Crawford, 1998; Pepper, 2009) utilised a scale-based instrument in an eating disorder sample. However, the scale formats used were sub-optimal. Two utilised an agreement scale with a neutral midpoint rating (Cachelin \& Striegel-Moore, 2006; Pepper, 2009), thereby reducing it to a dichotomous interpretation (presence or absence of barrier). Further, the interpretability of any summation of items (total scores) for these two scales is questionable. Scales such as these result in increased measurement error due to the neutral midpoint interfering with the direction of the scale. Such scales are often miscoded and interpreted as representing the middle point of the examined attribute (Hodge \& Gillespie, 2007). There are also limitations with the scale used by Crawford (1998). Factors were created without a thorough examination of scale structure or item contributions, limiting the interpretability of the scores.

There was also a lack of investigation of barriers across disorder groups. It is possible that specific treatment barriers (e.g. shame or availability of services) are more prominent for some disorders than others. Investigation across diagnostic groups would allow for the development of interventions to target the barriers most appropriate for each population.

An additional limitation in three of the studies that quantitatively assessed barriers (Cachelin et al., 2001; Cachelin \& Striegel-Moore, 2006; Pepper, 2009) was that barriers were 
only examined in those individuals who did not seek treatment. Whilst it is of interest to examine the factors preventing this sub-group of individuals from accessing treatment, it is important to recognise that delay in receiving treatment for an eating disorder is also of concern (Oakley Browne et al., 2006). Accordingly, individuals who have sought treatment also provide useful information regarding what factors may have delayed them receiving timely treatment. Rather than researchers focusing on treatment history when considering barriers, inclusion of individuals across any stage of the help-seeking process permits the greatest understanding of barriers in an eating disorder population. Despite this, only three studies (Dearden \& Mulgrew, 2013; Evans et al., 2011; Hepworth \& Paxton, 2007) examined the barriers irrespective of treatment history.

A final limitation concerns the unspecified nature of treatment/services in which these barriers were assessed. Nine of the studies examined barriers generally in the context of mental health care utilisation and failed to specify the source of professional help or type of treatment. The type of professional help sought can be from a variety of services and barriers have been shown to differ according to the professional source (Sheffield et al., 2004). Further, the type of treatment to be sought whether that is psychological, nutritional, or pharmacotherapy is a very important one given that barriers are likely to be different for each treatment. Therefore, it is clear that research within the area of eating disorders requires further specification of the type of treatment and the professional source when investigating treatment barriers.

\section{Conclusions and Future Directions}

The studies reviewed in this paper suggest there is an emerging awareness of the need to examine the factors preventing or delaying treatment seeking among eating disorder populations. However, most studies to date used qualitative approaches to understanding barriers to care in eating disorder populations, with only a small number utilising scale-based or checklist approaches. For adequate assessment of barriers, future research should utilise a scale-based 
instrument that permits a rating system whereby individuals can report the degree of interference each barrier may cause given that the relative importance of specific barriers differs widely across studies. Such an instrument should target all individuals in the eating disorders population and examine barriers specific to the types of treatment being offered. To this end, future research should focus on more rigorous scale development in this area through consultation with patients, clinicians, and experts. The adaptation of existing barriers to treatment measures to the specific populations and types of treatment will likely be a helpful starting point for researchers. Empirically validated measures of barriers to care in this population will help improve uptake and treatment outcomes for patients with eating disorders. 


\section{References}

Allen, K., \& Dixon, M. (1994). Psychometric assessment of the Allen barriers to treatment instrument. Substance Use \& Misuse, 29(5), 545-563.

Amato, P. R., \& Bradshaw, R. (1985). An exploratory study of people's reasons for delaying or avoiding helpseeking. Australian Psychologist, 20(1), 21-31.

Becker, A. E., Arrindell, A. H., Perloe, A., Fay, K., \& Striegel-Moore, R. H. (2010). A qualitative study of perceived social barriers to care for eating disorders: Perspectives from ethnically diverse health care consumers. International Journal of Eating Disorders, 43(7), 633-647.

Beckman, L. J., \& Amaro, H. (1984). Patterns of women's use of alcohol treatment agencies. Alcohol Health \& Research World.

Cachelin, F. M., Rebeck, R., Veisel, C., \& Striegel-Moore, R. H. (2001). Barriers to treatment for eating disorders among ethnically diverse women. International Journal of Eating Disorders, 30(3), 269-278.

Cachelin, F. M., \& Striegel-Moore, R. H. (2006). Help seeking and barriers to treatment in a community sample of Mexican American and European American women with eating disorders. International Journal of Eating Disorders, 39(2), 154-161.

Crawford, A. L. (1998). Environmental contexts and functional impairment associated with help-seeking and behavior change among women with bulimia. Dissertation Abstracts International: Section B: The Sciences and Engineering, 58(10-B), 5639.

Dearden, A., \& Mulgrew, K. E. (2013). Service provision for men with eating issues in Australia: An analysis of organisations', practitioners', and men's experiences. Australian Social Work, 66(4), 590-606. 
Escobar- Koch, T., Banker, J. D., Crow, S., Cullis, J., Ringwood, S., Smith, G., . . Schmidt, U. (2010). Service users' views of eating disorder services: an international comparison. International Journal of Eating Disorders, 43(6), 549-559.

Evans, E. J., Hay, P. J., Mond, J., Paxton, S. J., Quirk, F., Rodgers, B., . . Sawoniewska, M. A. (2011). Barriers to help-seeking in young women with eating disorders: A qualitative exploration in a longitudinal community survey. Eating Disorders: The Journal of Treatment \& Prevention, 19(3), 270-285.

Hart, L. M., Granillo, M. T., Jorm, A. F., \& Paxton, S. J. (2011). Unmet need for treatment in the eating disorders: a systematic review of eating disorder specific treatment seeking among community cases. Clinical psychology review, 31(5), 727-735.

Hepworth, N., \& Paxton, S. J. (2007). Pathways to help-seeking in bulimia nervosa and binge eating problems: A concept mapping approach. International Journal of Eating Disorders, 40(6), 493-504.

Hodge, D. R., \& Gillespie, D. F. (2007). Phrase completion scales: a better measurement approach than Likert scales? Journal of Social Service Research, 33(4), 1-12.

Keefe, S. E., \& Casas, J. M. (1980). Mexican Americans and mental health: A selected review and recommendations for mental health service delivery. American Journal of Community Psychology, 8(3), 303-326.

Leavey, G., Vallianatou, C., Johnson-Sabine, E., Rae, S., \& Gunputh, V. (2011). Psychosocial barriers to engagement with an eating disorder service: A qualitative analysis of failure to attend. Eating Disorders: The Journal of Treatment \& Prevention, 19(5), 425-440.

Marin, B. V. O., Marin, G., Padilla, A. M., \& De La Rocha, C. (1983). Utilization of traditional and non-traditional sources of health care among Hispanics. Hispanic Journal of Behavioral Sciences, 5(1), 65-80. 
Meyer, D. F. (2001). Help-seeking for eating disorders in female adolescents. Journal of College Student Psychotherapy, 15(4), 23-36.

Moher, D., Liberati, A., Tetzlaff, J., Altman, D. G., \& Group, P. (2010). Preferred reporting items for systematic reviews and meta-analyses: the PRISMA statement. International Journal of Surgery, 8(5), 336-341.

Mojtabai, R., Olfson, M., \& Mechanic, D. (2002). Perceived need and help-seeking in adults with mood, anxiety, or substance use disorders. Archives of General Psychiatry, 59(1), $77-84$.

Mokkink, L. B., Terwee, C. B., Patrick, D. L., Alonso, J., Stratford, P. W., Knol, D. L., . . de Vet, H. C. (2010). The COSMIN checklist for assessing the methodological quality of studies on measurement properties of health status measurement instruments: an international Delphi study. Quality of Life Research, 19(4), 539-549.

Mond, J. M., Hay, P., Rodgers, B., \& Owen, C. (2008). Mental health literacy and eating disorders: What do women with bulimic eating disorders think and know about bulimia nervosa and its treatment? Journal of Mental Health, 17(6), 565-575.

Oakley Browne, M. A., Elisabeth Wells, J., \& Mcgee, M. A. (2006). Twelve-month and lifetime health service use in Te Rau Hinengaro: the New Zealand mental health survey. Australian and New Zealand Journal of Psychiatry, 40(10), 855-864.

Pepper, A. C. (2009). Disordered eating, antifat attitudes, and barriers to treatment in college women from urban and rural areas. Dissertation Abstracts International: Section B: The Sciences and Engineering, 70(6-B), 3792.

Rapp, R. C., Xu, J., Carr, C. A., Lane, D. T., Wang, J., \& Carlson, R. (2006). Treatment barriers identified by substance abusers assessed at a centralized intake unit. Journal of substance abuse treatment, 30(3), 227-235. 
Reyes-Rodriguez, M. L., Ramirez, J., Davis, K., Patrice, K., \& Bulik, C. M. (2013). Exploring barriers and facilitators in eating disorders treatment among Latinas in the United States. Journal of Latina/o Psychology, 1(2), 112-131.

Rickwood, D. J., \& Braithwaite, V. A. (1994). Social-psychological factors affecting helpseeking for emotional problems. Social science \& medicine, 39(4), 563-572.

Sheffield, J. K., Fiorenza, E., \& Sofronoff, K. (2004). Adolescents' willingness to seek psychological help: Promoting and preventing factors. Journal of Youth and Adolescence, 33(6), 495-507.

Stefl, M. E., \& Prosperi, D. C. (1985). Barriers to mental health service utilization. Community Mental Health Journal, 21(3), 167-178.

Thompson, A., Hunt, C., \& Issakidis, C. (2004). Why wait? Reasons for delay and prompts to seek help for mental health problems in an Australian clinical sample. Social psychiatry and psychiatric epidemiology, 39(10), 810-817.

Thompson, C., \& Park, S. (2016). Barriers to access and utilization of eating disorder treatment among women. Archives of Women's Mental Health, 1-8.

Tucker, J. A. (1995). Predictors of help- seeking and the temporal relationship of help to recovery among treated and untreated recovered problem drinkers. Addiction, 90(6), 805809.

Vanheusden, K., Mulder, C. L., van der Ende, J., van Lenthe, F. J., Mackenbach, J. P., \& Verhulst, F. C. (2008). Young adults face major barriers to seeking help from mental health services. [Article]. Patient Education and Counseling, 73(1), 97-104. doi: 10.1016/j.pec.2008.05.006 
2067 records identified through database searching $($ PsycINFO $=1216)$ $($ PubMed $=851)$
No additional records generated through manual search, 1 additional record identified through reference list search

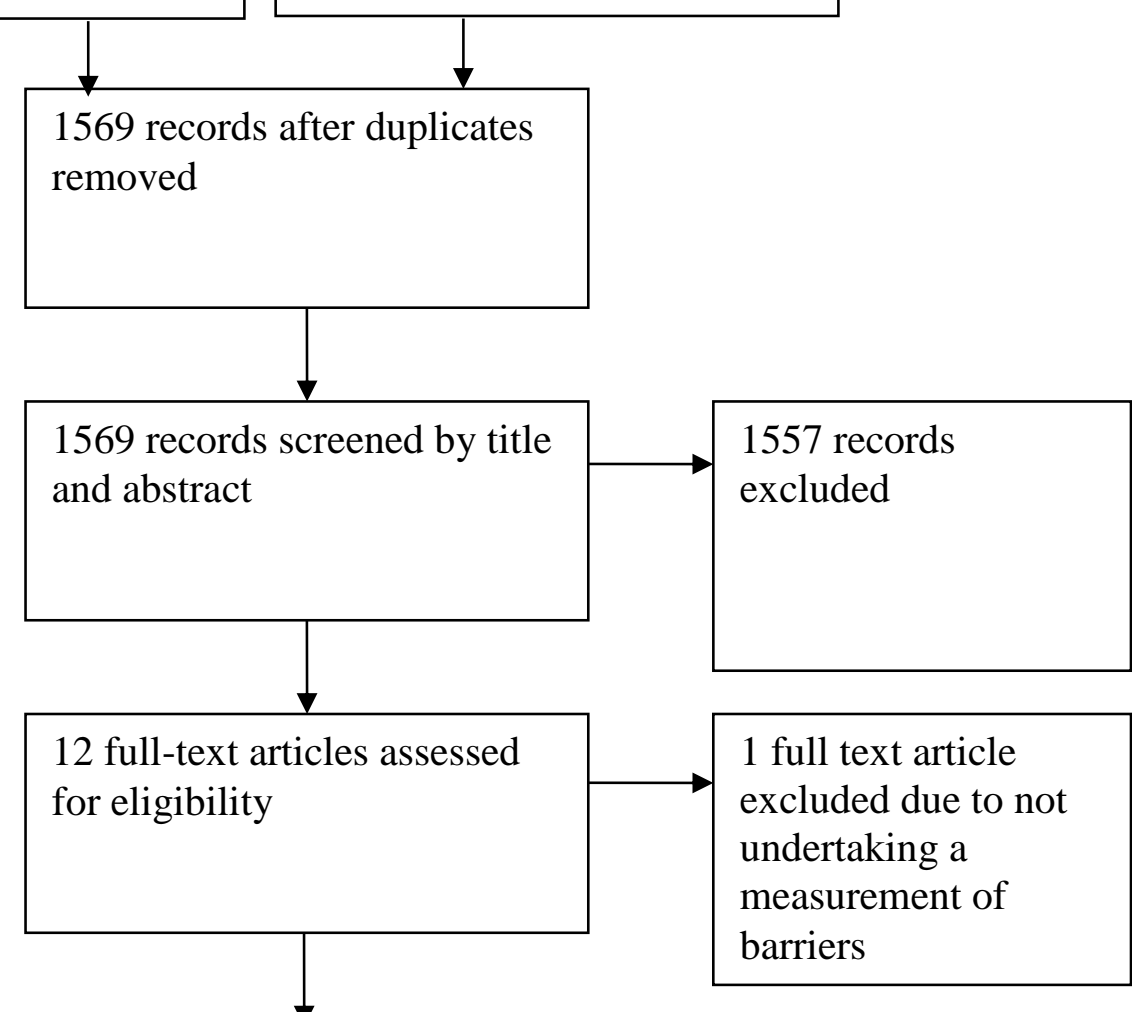

11 studies used in qualitative synthesis

Figure 1. Flowchart showing results of the systematic review for studies investigating treatment barriers for eating disorders. 
Table 1

Sample Characteristics and Assessment Format of Studies Examining Treatment Barriers in Eating Disorder Samples

\begin{tabular}{|c|c|c|c|c|c|c|c|c|c|}
\hline \multirow[t]{2}{*}{ Study } & \multicolumn{5}{|c|}{ Sample Characteristics } & \multicolumn{3}{|c|}{ Assessment Format } & \multirow{2}{*}{$\begin{array}{c}\text { Psychometric } \\
\text { properties }\end{array}$} \\
\hline & Participants & Recruitment & Age & $N$ & Diagnoses & Assessment method & Response format & $\begin{array}{l}\text { Treatment/ } \\
\text { provider }\end{array}$ & \\
\hline $\begin{array}{l}\text { Becker et al. } \\
(2010)\end{array}$ & $\begin{array}{l}\text { American } \\
\text { adults with } \\
\text { past or current } \\
\text { ED }\end{array}$ & $\begin{array}{l}\text { Subset from } \\
\text { larger national } \\
\text { ED study }\end{array}$ & $\begin{array}{l}\text { Range }=\text { Not } \\
\text { reported } \\
M=\text { Not reported } \\
S D=\text { Not } \\
\text { Reported }\end{array}$ & $N=32$ & Not specified & $\begin{array}{l}\text { Interview, open } \\
\text { question }\end{array}$ & $\begin{array}{l}\text { Open-ended } \\
\text { response }\end{array}$ & $\begin{array}{l}\text { Not } \\
\text { specified }\end{array}$ & N/A \\
\hline $\begin{array}{l}\text { Cachelin et al. } \\
(2001)\end{array}$ & $\begin{array}{l}\text { Ethnically } \\
\text { diverse } \\
\text { community } \\
\text { sample }\end{array}$ & $\begin{array}{l}\text { Community } \\
\text { advertisement }\end{array}$ & $\begin{array}{l}\text { Range }=\text { Not } \\
\text { reported } \\
M=30.8 \\
S D=\text { Not } \\
\text { Reported }\end{array}$ & $N=61 *$ & $\begin{array}{l}\text { BED (33) } \\
\text { BN (17) } \\
\text { AN (5) } \\
\text { EDNOS (6) }\end{array}$ & $\begin{array}{l}\text { Interview, utilised } \\
\text { checklist format, } \\
\text { read a list of } 11 \\
\text { reasons for not } \\
\text { seeking help }\end{array}$ & $\begin{array}{l}\text { Dichotomous } \\
\text { (yes/no) response }\end{array}$ & $\begin{array}{l}\text { Not } \\
\text { specified }\end{array}$ & Not assessed \\
\hline $\begin{array}{l}\text { Cachelin \& } \\
\text { Striegel- } \\
\text { Moore } \\
(2006)\end{array}$ & $\begin{array}{l}\text { Mexican or } \\
\text { European } \\
\text { American } \\
\text { females }\end{array}$ & $\begin{array}{l}\text { Community } \\
\text { advertisement }\end{array}$ & $\begin{array}{l}\text { Range }=\text { Not } \\
\text { reported } \\
M=28 \\
S D=\text { Not } \\
\text { reported }\end{array}$ & $N=145^{*}$ & $\begin{array}{l}\text { AN (15) } \\
\text { BED (47) } \\
\text { BN (53) } \\
\text { EDNOS (30) }\end{array}$ & $\begin{array}{l}\text { Self-report scale- } \\
\text { based instrument, } \\
19 \text { items }\end{array}$ & $\begin{array}{l}\text { 5-point Likert scale, } \\
\text { rated level of } \\
\text { agreement with } \\
\text { barriers }\end{array}$ & $\begin{array}{l}\text { Not } \\
\text { specified }\end{array}$ & $\begin{array}{l}\text { Not assessed/ } \\
\text { reported }\end{array}$ \\
\hline $\begin{array}{l}\text { Crawford } \\
(1998)\end{array}$ & $\begin{array}{l}\text { American } \\
\text { females with } \\
\text { BN }\end{array}$ & $\begin{array}{l}\text { Community } \\
\text { advertisement } \\
\text { and } \\
\text { undergraduate } \\
\text { psychology } \\
\text { students }\end{array}$ & $\begin{array}{l}\text { Range }=\text { Not } \\
\text { reported } \\
M=23.2 \\
S D=7.6\end{array}$ & $N=49^{*}$ & $\begin{array}{l}\text { BN (39) } \\
\text { Hx of BN (10) }\end{array}$ & $\begin{array}{l}\text { Interview, utilised } \\
\text { scale format, read a } \\
\text { list of } 20 \text { reasons } \\
\text { for not seeking help }\end{array}$ & $\begin{array}{l}\text { 10-point rating } \\
\text { scale, rated degree } \\
\text { to which they were } \\
\text { influenced by each } \\
\text { barrier }\end{array}$ & $\begin{array}{l}\text { Not } \\
\text { specified }\end{array}$ & $\begin{array}{l}\text { No formal } \\
\text { investigation, } \\
\text { but item } \\
\text { correlations } \\
\text { used to } \\
\text { create } 7 \\
\text { treatment } \\
\text { barrier } \\
\text { factors }\end{array}$ \\
\hline $\begin{array}{l}\text { Dearden \& } \\
\text { Mulgrew } \\
(2013)\end{array}$ & $\begin{array}{l}\text { Australian } \\
\text { males with } \\
\text { disordered } \\
\text { eating }\end{array}$ & $\begin{array}{l}\text { Community } \\
\text { advertisement } \\
\text { and } \\
\text { practitioner }\end{array}$ & $\begin{array}{l}\text { Range }=22-58 \\
M=34.2 \\
S D=16.8\end{array}$ & $N=5$ & Not specified & $\begin{array}{l}\text { Questionnaire, open } \\
\text { question }\end{array}$ & $\begin{array}{l}\text { Open-ended } \\
\text { response }\end{array}$ & $\begin{array}{l}\text { Not } \\
\text { specified }\end{array}$ & N/A \\
\hline
\end{tabular}


referra

\begin{tabular}{|c|c|c|c|c|c|c|c|c|c|}
\hline $\begin{array}{l}\text { Evans et al. } \\
\text { (2011) }\end{array}$ & $\begin{array}{l}\text { Australian } \\
\text { Adults }\end{array}$ & $\begin{array}{l}\text { Part of a larger } \\
\text { health and } \\
\text { wellbeing } \\
\text { study }\end{array}$ & $\begin{array}{l}\text { Range }=\text { Not } \\
\text { reported } \\
M=33 \\
S D=\text { Not } \\
\text { reported }\end{array}$ & $N=57$ & $\begin{array}{l}\text { BN (7) } \\
\text { BED (8) } \\
\text { EDNOS(30) } \\
\text { Sub-clinical } \\
(12)\end{array}$ & $\begin{array}{l}\text { Interview, open } \\
\text { question }\end{array}$ & $\begin{array}{l}\text { Open-ended } \\
\text { response }\end{array}$ & $\begin{array}{l}\text { Not } \\
\text { specified }\end{array}$ & N/A \\
\hline $\begin{array}{l}\text { Hepworth \& } \\
\text { Paxton (2007) }\end{array}$ & $\begin{array}{l}\text { Australian } \\
\text { females with } \\
\text { BN or BED }\end{array}$ & $\begin{array}{l}\text { Community } \\
\text { advertisement }\end{array}$ & $\begin{array}{l}\text { Range }=18-62 \\
M=33.8 \\
S D=12.3\end{array}$ & $N=63$ & $\begin{array}{l}\text { Hx of BN (28), } \\
\operatorname{BED}(17), A N \\
\& \operatorname{BN}(7), B N \\
\& \operatorname{BED}(4) \text { and } \\
\text { EDNOS (7) }\end{array}$ & $\begin{array}{l}\text { Interview, open } \\
\text { question }\end{array}$ & $\begin{array}{l}\text { Open-ended } \\
\text { response }\end{array}$ & $\begin{array}{l}\text { Not } \\
\text { specified }\end{array}$ & N/A \\
\hline $\begin{array}{l}\text { Leavey et al. } \\
(2011)\end{array}$ & $\begin{array}{l}\text { Adults referred } \\
\text { to a London } \\
\text { ED outpatient } \\
\text { clinic }\end{array}$ & $\begin{array}{l}\text { Eating disorder } \\
\text { clinic referrals }\end{array}$ & $\begin{array}{l}\text { Range }=\text { Not } \\
\text { reported } \\
M=\text { Not reported } \\
S D=\text { Not } \\
\text { reported }\end{array}$ & $N=13$ & Not specified & $\begin{array}{l}\text { Interview, open } \\
\text { question }\end{array}$ & $\begin{array}{l}\text { Open-ended } \\
\text { response }\end{array}$ & $\begin{array}{l}\text { Specialised } \\
\text { ED } \\
\text { outpatient } \\
\text { service }\end{array}$ & N/A \\
\hline Meyer (2001) & $\begin{array}{l}\text { American } \\
\text { female high } \\
\text { school } \\
\text { students }\end{array}$ & $\begin{array}{l}\text { Two public } \\
\text { high schools }\end{array}$ & $\begin{array}{l}\text { Range }=15-19 \\
M=17.8 \\
S D=\text { Not } \\
\text { reported }\end{array}$ & $N=238^{*}$ & $\begin{array}{l}\text { AN (1), BN (2), } \\
\text { EDNOS (35), } \\
\text { Sub-clinical } \\
(78), \\
\text { asymptomatic } \\
(122)\end{array}$ & $\begin{array}{l}\text { Self-report } \\
\text { checklist, } 6 \text { reasons } \\
\text { for not seeking help }\end{array}$ & $\begin{array}{l}\text { Dichotomous } \\
\text { yes/no, 'other' } \\
\text { option to list } \\
\text { additional barriers }\end{array}$ & $\begin{array}{l}\text { Professional } \\
\text { counselling }\end{array}$ & Not assessed \\
\hline Pepper (2009) & $\begin{array}{l}\text { American } \\
\text { college } \\
\text { females aged } \\
18 \text { years or } \\
\text { older }\end{array}$ & $\begin{array}{l}\text { Students } \\
\text { enrolled in } \\
\text { undergraduate } \\
\text { psychology } \\
\text { courses }\end{array}$ & $\begin{array}{l}\text { Range }=18.0- \\
45.0 \\
M=20.08 \\
S D=3.59\end{array}$ & $N=106^{*}$ & $\begin{array}{l}\text { Not specified - } \\
\text { Disordered } \\
\text { Eating } \\
\text { Population }\end{array}$ & $\begin{array}{l}\text { Self-report scale- } \\
\text { based instrument, } \\
26 \text { reasons for not } \\
\text { seeking help }\end{array}$ & $\begin{array}{l}\text { 5-point Likert scale, } \\
\text { rated level of } \\
\text { agreement with } \\
\text { barriers }\end{array}$ & $\begin{array}{l}\text { Not } \\
\text { specified }\end{array}$ & \\
\hline $\begin{array}{l}\text { Reyes- } \\
\text { Rodriguez, } \\
\text { Ramirez, } \\
\text { David, Patrice } \\
\text { \& Bulik } \\
(2013)\end{array}$ & $\begin{array}{l}\text { Latino adults } \\
\text { with a past or } \\
\text { current eating } \\
\text { disorder }\end{array}$ & $\begin{array}{l}\text { Community } \\
\text { advertisement }\end{array}$ & $\begin{array}{l}\text { Range: } 26-38 \\
M=31.2 \\
S D=\text { Not } \\
\text { reported }\end{array}$ & $N=5$ & $\begin{array}{l}\text { Hx of BN (3), } \\
\text { BED (1) and } \\
\text { sub-threshold } \\
\text { binge eating (1) }\end{array}$ & $\begin{array}{l}\text { Interview, open } \\
\text { question }\end{array}$ & $\begin{array}{l}\text { Open-ended } \\
\text { response }\end{array}$ & $\begin{array}{l}\text { Not } \\
\text { specified }\end{array}$ & N/A \\
\hline
\end{tabular}

* A smaller subsample of the total participant pool completed the barriers to treatment measures in each of these studies.

Note. $\mathrm{AN}=$ Anorexia Nervosa, $\mathrm{BN}=$ Bulimia Nervosa, EDNOS $=$ Eating Disorder Not Otherwise Specified, BED = Binge Eating Disorder, Hx $=$ history, ED = Eating

Disorder. 
Table 2

Types of Treatment Barriers Identified in Disordered Eating Samples

\begin{tabular}{|c|c|c|c|c|c|c|c|}
\hline & $\begin{array}{l}\text { Becker et al. } \\
(2010)\end{array}$ & $\begin{array}{l}\text { Cachelin et al. } \\
\text { (2001) }\end{array}$ & $\begin{array}{l}\text { Cachelin \& } \\
\text { Striegel-Moore } \\
(2006)\end{array}$ & Crawford (1998) & $\begin{array}{l}\text { Dearden \& } \\
\text { Mulgrew (2013) }\end{array}$ & $\begin{array}{l}\text { Evans et al. } \\
(2011)\end{array}$ & $\begin{array}{l}\text { Hepworth \& } \\
\text { Paxton (2007) }\end{array}$ \\
\hline \multirow[t]{5}{*}{$\begin{array}{l}\text { Barriers } \\
\text { identified }\end{array}$} & Shame and stigma & $\begin{array}{l}\text { Financial } \\
\text { difficulties }\end{array}$ & Shame & $\begin{array}{l}\text { Preference to } \\
\text { solve problem on } \\
\text { their own }\end{array}$ & $\begin{array}{l}\text { Lack of } \\
\text { awareness of } \\
\text { nature of problem } \\
\text { and treatment } \\
\text { options }\end{array}$ & $\begin{array}{l}\text { Unhelpful past } \\
\text { experiences with } \\
\text { professionals }\end{array}$ & Fear of stigma \\
\hline & Social stereotypes & $\begin{array}{l}\text { Belief that } \\
\text { others cannot } \\
\text { help }\end{array}$ & $\begin{array}{l}\text { Not knowing } \\
\text { where to go }\end{array}$ & $\begin{array}{l}\text { Problem not } \\
\text { serious enough }\end{array}$ & Motivation & Cost & $\begin{array}{l}\text { Low mental health } \\
\text { literacy/Perception } \\
\text { of need for } \\
\text { treatment }\end{array}$ \\
\hline & $\begin{array}{l}\text { Availability of } \\
\text { care }\end{array}$ & $\begin{array}{l}\text { Fear of being } \\
\text { labelled }\end{array}$ & $\begin{array}{l}\text { Belief that one } \\
\text { should help } \\
\text { themselves }\end{array}$ & $\begin{array}{l}\text { Concerns about } \\
\text { privacy, labelling, } \\
\text { or discussing } \\
\text { behaviours }\end{array}$ & $\begin{array}{l}\text { Lack of } \\
\text { recognition of } \\
\text { men's eating } \\
\text { issue in health } \\
\text { system }\end{array}$ & Lack of time & Shame \\
\hline & $\begin{array}{l}\text { Affordability of } \\
\text { care }\end{array}$ & $\begin{array}{l}\text { Not aware of } \\
\text { available } \\
\text { resources }\end{array}$ & $\begin{array}{l}\text { Fear of being } \\
\text { labelled }\end{array}$ & $\begin{array}{l}\text { Belief treatment } \\
\text { would not help }\end{array}$ & $\begin{array}{l}\text { Usefulness of } \\
\text { treatment }\end{array}$ & $\begin{array}{l}\text { Service } \\
\text { eligibility/ } \\
\text { restrictions }\end{array}$ & Fear of change \\
\hline & & $\begin{array}{l}\text { Feelings of } \\
\text { shame }\end{array}$ & $\begin{array}{l}\text { Problems not } \\
\text { severe enough }\end{array}$ & Cost & Cost & $\begin{array}{l}\text { Personal/ } \\
\text { emotional issues } \\
\text { - Low motivation } \\
\text { to change } \\
\text { - Shame }\end{array}$ & Cost \\
\hline
\end{tabular}

Note. Barriers are reported in order of endorsement, with the most commonly reported barriers listed first. For the four quantitative studies that utilised a scale or checklist, the top five most endorsed barriers are listed. 
Table 2 (cont.)

Types of Treatment Barriers Identified in Disordered Eating Samples

\begin{tabular}{llll}
\hline $\begin{array}{l}\text { Leavey et al. (2011) } \\
\begin{array}{l}\text { Complexity of } \\
\text { psychological } \\
\text { difficulties }\end{array}\end{array}$ & $\begin{array}{l}\text { Problem not } \\
\text { worrisome enough }\end{array}$ & $\begin{array}{l}\text { Problem not serious } \\
\text { enough }\end{array}$ & $\begin{array}{l}\text { Lack of info about } \\
\text { al. (2013) }\end{array}$ \\
$\begin{array}{l}\text { Function that ED } \\
\text { serves }\end{array}$ & $\begin{array}{l}\text { Do not believe they } \\
\text { have a problem }\end{array}$ & $\begin{array}{l}\text { Belief that one should } \\
\text { help themselves }\end{array}$ & Language \\
$\begin{array}{l}\text { Past treatment } \\
\text { experiences }\end{array}$ & $\begin{array}{l}\text { Do not want parents } \\
\text { to know }\end{array}$ & $\begin{array}{l}\text { Seeking support from } \\
\text { others }\end{array}$ & Economic barriers \\
$\begin{array}{l}\text { Expectations of } \\
\text { treatment }\end{array}$ & $\begin{array}{l}\text { Fear of } \\
\text { psychotherapy }\end{array}$ & Financial difficulties & $\begin{array}{l}\text { Emotional/ } \\
\text { personal barriers }\end{array}$ \\
$\begin{array}{l}\text { Service- specific } \\
\text { - Long wait time } \\
\text { - Inflexibility } \\
\text { - Discontinuity of } \\
\text { care }\end{array}$ & $\begin{array}{l}\text { Do not want others to } \\
\text { know }\end{array}$ & Fear of being labelled & Cultural stigmas \\
\hline
\end{tabular}

